\title{
The Current Situation and Strategy of College English Translation Teaching
}

\author{
CHEN Meng-jie, SHI Xi-chun \\ Changchun University, Changchun, China
}

\begin{abstract}
College English translation teaching is an important part of college English teaching. It is the principal way to train translators. However, there are too many problems in the process of college English translation teaching and it is really out-dated. Therefore, it is a must to improve college English translation teaching, complete the teaching contents, improve the curriculum provision, explore positive teaching modes, intensify the training of the teachers, and enhance the students translation skills, so that the colleges could provide highly-qualified translators for the society.
\end{abstract}

Keywords: college English, translation teaching, teaching mode

\section{Introduction}

In the process of economic globalization, the demand for outstanding foreign language translation talents are increasing, however, there are many urgent problems and shortcomings in university English translation teaching, seriously obstructing the training of excellent translation talents. This paper analyzes the necessity of strengthening university English translation teaching, sums up the present situation and problems of current university English translation teaching, as well as suggestions and measures to solve the problems are given, which plays certain reference and guidance role in further improving the university English translation teaching.

\section{College English Translation Teaching}

At present, in various colleges and universities, as a compulsory course in the stage of basic teaching, college English mainly is divided into two aspects: intensive reading course of college English and college English listening and speaking course. From the overall perspective of the curriculum, English listening, speaking, reading, and writing of the five basic skills stand a large proportion, while the teaching content of "translation" is very little. At the same time, from any point of view of higher learning institutions, teachers and students, there is not enough emphasis on the translation teaching. The teaching of college English translation has been seriously out of line with our country's economic development and social needs, and the teaching effect of English translation teaching is worrying. To sum up, there are some problems in college English translation teaching as following.

CHEN Meng-jie, lecturer, master, Public Foreign Language Teaching and Research Department, Changchun University. SHI Xi-chun, lecturer, master, Public Foreign Language Teaching and Research Department, Changchun University. 


\section{The Design of the Textbook Is Not Reasonable and the Curriculum Is Unreasonable}

Translation theory and translation skills are the basis of translation practice. However, through an overview of several national college English textbooks, any introduction about the based translation theories and translation methods and skills commonly used cannot be found. This present situation causes the translation teaching activity to be confined to the translation exercises which are set around the text contents, and these so-called translation exercises are just a comprehensive practice of grammar and vocabulary in the strict sense. These preparations of teaching materials put the translation teaching in a kind of dispensable subordination place, making the majority of teachers and students mistakenly think that listening, speaking, reading, and writing are the focus of college English teaching, which finally results in a lack of translation ability training for students.

In the curriculum setting, most of the college English courses do not offer an independent translation course. And senior students are required to take courses in college English four to five hours a week, among them one hour for audio-visual teaching, and the rest are for intensive reading and extensive reading, which makes the translation teaching have no class time available. Even the College English Curriculum Requirements have made further demands of translation competence; the embarrassing position of college English translation teaching has not been changed.

\section{Teaching Mode Is Stale and Single}

At present, in some conditional colleges opening college English translation course, most translation teaching is still limited to the traditional model where the teacher is the main body of the class, the traditional "spoon feeding" teaching methods, while students passively accept, and rarely have the opportunity to make translation practice in the real context. In the traditional mode, students can lay a solid foundation of basic language knowledge, as well as the reading ability, but it neglects the initiative of students' participation, resulting that the teaching method is not flexible with the lack of the interaction between teachers and students.

\section{Weak Teachers Strength}

At present, the vast majority of college English teachers are not the graduates be of the research direction of translation, they are lack of translation theory, and often powerless in the teaching process. In addition, most of the students in colleges and universities in China are non-English majors, which makes their professional knowledge rarely applied to classroom teaching in university stage, and their own translation theory, practice ability, and teaching level are far from being able to meet the needs of society. Moreover, because of the expansion of the enrollment scale in colleges, the number of students has increased dramatically, resulting that the proportion of college English teachers and students is not enough. Besides that, the vast majority of teachers working diligently in translation teaching stand heavy teaching tasks; they do not have time and energy to participate in business education, and are also too busy to be interested in the world's advanced translation theories and teaching methods, which results in many translation teachers feeling powerless. Thus, there is a teaching situation, that is, "hand is insufficient, while the expert is less" (YANG, 2010, p. 56).

\section{Comprehensive Language Use Ability of the Students Is Poor}

There often appear a phenomenon in college English teaching that students understand the meaning of an English article, or the key paragraph, but it is not so easy to translate it in Chinese. Even if they can translate, just finish it in accordance with the original structure of literal sentences, the result is not ideal. The poor quality of 
language and the lack of understanding directly lead to the low level of the students' translation, as well as restrict the improvement of students' comprehensive English.

In addition, it is well known that every language has its own context semantics and cultural background. The students' misunderstanding of the original context and cultural background will make them not correctly grasp the meanings, and also inevitably make a mistake in translation.

\section{Strategies to Improve the College English Translation Teaching}

\section{Improve the Teaching Material Content and Curriculum Setting}

Teaching material is an important carrier of teaching content which should be updated. Teachers should increase the introduction of theoretical knowledge of translation and translation skills. In the course of teaching, teachers should teach students some basic translation theories, such as what the translation is, what the standard is, the concept of literal translation and free translation, so that students will understand the translation theory, and improve their accuracy and speed of translation. In addition, it is of great value to appropriately increase the content of science, technology, economy, and international politics, and carry out the translation practice of the new professional and high-tech words.

Reforming curriculum setting, increasing the intensity of teaching translation in the foundation stage, and making the translation teaching with listening, speaking, reading, and writing teaching go hand in hand. After the students enter the high grade, conditional colleges can regularly held a number of activities, such as translation lectures and translation salon, which can also open courses including the relevant translation according to the requirements of the syllabus for college English teaching, such as contrast between English and Chinese, Western culture, culture and translation, and so on, so as to provide the conditions for the cultivation of students' translation competence.

\section{Explore Effective Teaching Mode}

Many scholars have done a lot of research and published many academic papers based on the mode of translation teaching. YE Miao (2007) puts forward the interactive mode of translation teaching; YANG Min and ZHAO Jin-dong (2008) make a research on the application of exploring mode in translation. WEN Jun (2005) puts forward and discusses the teaching mode, task mode, situational teaching mode, and multimedia network environment based on the theory of "people oriented", which is very useful for improving the traditional models. The success of college English translation teaching depends largely on whether the teaching mode is reasonable or not. Therefore, the teaching of college English translation should follow the principle of "students as the main body", draw lessons from the research results of predecessors, and explore effective teaching mode to stimulate students' learning interest and improve their translation level.

\section{Strengthen the Cultivation of the Teachers' Quality}

College English translation teaching requires that teachers must have a certain translation theory and classroom organization skills. At the same time, the qualified translation teachers should have the relevant practical experience. Therefore, the urgent task of the university at present is to adjust and train teachers, as well as build a high-quality translation teaching and research team in order to improve the college translation teaching and the students' translation level, which will meet the needs of the actual market for translation talents. The 
teachers should strengthen their own cultivation, calm down, and constantly enrich themselves to improve their business level in the course of the study and training. At the same time, we should pay close attention to the frontier of this subject, also learn the advanced theory of foreign countries combined with the actual situation. Of course, the university's management unit should also carry on the teacher training about modern technology, so that they have the modern education skills.

In addition, college English teachers should strengthen the understanding of the culture of the world and have a wide range of knowledge. Besides that, conditional colleges, especially with the translation system and translation professional master, doctoral students, should open the relevant translation courses, or open a training course making the use of holidays, and encourage teachers to study or conduct special training to meet the needs of teaching.

\section{Pay Attention to Cultivate Students' Comprehensive Ability of Language Use}

To improve the translation level of students, teachers must first change the students' understanding of the translation errors, so that they can realize that translation, listening, speaking, reading, and writing skills are equally important. In the teaching process, teachers should continuously improve the teaching methods, explore the effective teaching mode, as well as stimulate students' interest in learning, which will lay a good language foundation for them. Second, strengthen the cultivation of students' translation ability. In the process of translation teaching, teachers should guide students to have a good understanding of cultural differences between Chinese and Western language. At the same time, the teachers must help students eliminate the cultural barriers through analyzing the cultural background, thus reducing mistranslation, errors and omissions, and other phenomena. Once again, be bold to use translation techniques. Encourage students to try some mature translation software, and to put the modern information technology into the translation teaching activities, which will greatly meet the needs of the market.

\section{Conclusion}

As the main position to cultivate English translation talents with high level, college English teaching stands the task of cultivating translation talents, especially the technical translators. However, the current situation of college English translation teaching is worrying, which has seriously restricted the cultivation of translation talents in the new period. Therefore, the competent departments at all levels and the national colleges should promote the reform of college English teaching, improve the teaching content and curriculum setting through improving College English teaching, as well as explore the effective teaching mode, pay attention to cultivate students' comprehensive ability of language use, so as to cultivate more and more translator talent with a high level of translation.

\section{References}

CHENG, H. P. (2006). Research on the cultivation and improvement of the quality of college teachers in China. Journal of Henan Mechanical and Electrical Engineering College, 45(11), 103-105.

SHI, R. (2010). New teaching mode of college English translation: Students as the center. Journal of Dongnan Vocational and Technical College, 64(6), 35-37.

WEN, J. (2005). Research on translation curriculum model: The development of translation competence as the center. Beijing: China Literature Press. 
YANG, M., \& ZHAO, J. D. (2008). The application of inquiry mode in English and Chinese translation teaching: A case study of the translation of the target text. Journal of Anhui Vocational and Technical College, 12(3), 78-80.

YANG, R. L. (2010). Research on the cultivation of middle school students' translation ability in college English translation teaching. Neijiang Science and Technology, 30(14), 56.

YE, M. (2007). The interactive mode of translation teaching and learning in the field of translation studies. Foreign Literature, $34(22), 51-56$.

YIN, C. (2009). The current situation of college English translation teaching and its countermeasures. Chinese School Education, 67(27), 112.

ZHANG, H. R. (2010). The existing problems and countermeasures of college English translation teaching. Education Theory and Practice, 51(30), 62-63. 